\title{
Cytotoxic Activity and Apoptosis Induction of Ethanolic Extract of Pericarps of Mangosteen (Garcinia mangostana Linn.) on WiDr Cells and Interaction Study of Alpha-mangosteen to IKK and VEGF Based on Molecular Docking
}

\author{
Annishfia Lailatur Rohmah, Fikri Amalia, Erlina Rivanti, Dyaningtyas Dewi \\ Pamungkas Putri, Nunuk Aries Nurulita* \\ Cancer Chemoprevention Research Center, Faculty of Pharmacy, Universitas Gadjah Mada, Yogyakarta, \\ Indonesia
}

\begin{abstract}
One of the compounds found efficacious as an anti-proliferative on colon cancer is alpha-mangosteen, a xanthon compound that is abundant in pericarp of mangosteen. This study focused to evaluate anticancer activity of the ethanolic extract of pericarp of mangosteen (Garcinia mangostana Linn.) on WiDr colon cancer cells and to observe the affinity of alpha-mangosteen in inhibiting IKK and VEGF. Cytotoxic effect was tested by MTT assay and apoptosis induction was evaluated by double staining method on WiDr colon cancer cells, while interaction between alpha-mangosteen to the receptors was measured by molecular docking. The ethanolic extract was proven to have cytotoxic activity against $\mathrm{WiDr}$ colon cancer cells with $\mathrm{IC}_{50}$ of $25 \mu \mathrm{g} / \mathrm{mL}$. In addition, the observation of apoptosis induction by double-staining method showed that apoptosis associated the cytotoxic effect of ethanolic extract of pericarp of mangosteen (EPM) on WiDr colon cancer cells. Molecular docking showed that active compounds in pericarp of mangosteen could compete with the native ligand of VEGF because the docking score of alpha-mangosteen was almost equal with native ligand. From these results we could be concluded that the cytotoxic effect of EPM to WiDr cells was mediated by cell apoptosis. This extract was potential to be developed as chemopreventive agent.
\end{abstract}

Keyword : Garcinia mangostana Linn., cytotoxic effect, apoptosis, WiDr cell, molecular docking

\section{INTRODUCTION}

Colon cancer is the fourth leading cause of death. Colon cancer incidence rates continue to increase along with population growth in both developing and developed countries (Winawer, 2007). In colon cancer, increased expression of cyclooxygenase-2 (COX-2) induce the formation of prostaglandin (PGE2) from arachidonic acid. It is related to the regulation of cell proliferation, differentiation, and tumorigenesis (Turini and Dubois, 2002). Overexpression of COX-2 associates with the activation of NF- $\kappa B$. NF- $\kappa B$ is activated by phosphorylation of IKB, an inhibitor of protein

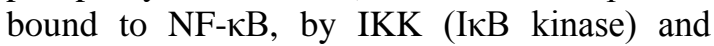
resulted in the outbreak of the bond between NF- $\kappa B$ and I $\kappa B$. Induction of NF- $\kappa B$ showed the inhibition of apoptosis and increase of proliferation of cancer cells thus inhibition of $\mathrm{NF}-\mathrm{\kappa B}$ suppressed tumorigenesis and metastasis and decreased VEGF expression in some cancer cells (Fujioka, et al., 2003). Therefore, inhibition of NF- $\mathrm{BB}$ activation through suppression of IKK, inhibiting the expression of COX-2 and VEGF may be one specific target in colon cancer chemoprevention.

Until now, the result for cancer treatment is still unsatisfactory. Therefore, the study of cancer drug discovery is still intensively conducted. One of the medicinal plants that become the object of study is the pericarp of the mangosteen fruit.

*Corresponding author email: nunuknurulita@yahoo.com 
Based on in vitro assays, DLD-1 cells (human colon cancer cell model) showed that the mangosteen pericarp extract can inhibit cancer cell growth at low doses of 5-20 $\mu \mathrm{m}$ (Matsumoto, et al., 2005). Water extract, 50 and $95 \%$ ethanol, ethyl acetate of pericarp of mangosteen has antioxidant activity against free radical 2,2-diphenyl-1-pikrlhidrazil (Weecharangsan, et al., 2006). Alphamangosteen as the main compound of mangosteen pericarps extract can reduce the occurrence of focal lesions and rat colonic epithelium induced 1.2-dimetilhidrazin (DMH) (Nabandith, et al., 2004). The findings became the basis for further development of the mangosteen pericarp extracts as chemopreventive agents especially colon cancers.

Mangosteen pericarp that usually discarded can turn into a potential chemopreventive agent. This study was to test the cytotoxicity of ethanolic extract of pericarp of mangosteen to the WiDr cell as another model for colon cancer besides DLD-1. WiDr cell line was chosen because it reportedly safe for use in a variety of cytotoxic tests, easily for cultured and treatment. The cytotoxic effect was determined by MTT assay. Furthermore, the effect of ethanolic extract of mangosteen pericarp (Garcinia mangostana Linn.) against WiDr cell on apoptosis induction were observed. The observation of the effect of apoptosis induction was done by doublestaining method. This research also studied the inhibitory effect of NF- $\mathrm{KB}$ expression through suppression of IKK, as well as inhibition of the expression of VEGF by ethanolic extract of pericarp of mangosteen (Garcinia mangostana Linn.) by using molecular docking. The results of this study are expected to provide scientific evidence regarding the cytotoxic activity of ethanolic extract of pericarp of mangosteen (EPM) and apoptosis induction against $\mathrm{WiDr}$ colon cancer cells so it can be a basis for the use of natural materials as a chemopreventive agent to prevent the incidence of cancer.

\section{MATERIALS AND METHODS}

\section{Molecular Docking}

Molecular docking method were done to know the interaction between alpha-mangosteen as the main compound of mangosteen pericarps extract to binding site of IKK and VEGF. The structure of alpha-mangosteen was drawn by
Marvin Sketch Software. The structure of protein complex was taken from the Protein Data Bank (PDB) sites (http://www.pdb.org/pdb/home/home.do). The PDB ID for IKK and VEGF were 2 GNG and 2P2I respectively. The analysis was done to get the docking score to show the interaction affinity between the ligand and the protein receptor. The affinity increases as the docking score value reduces.

\section{Extraction}

Mangosteen (Garinia mangostana Linn from Purworejo, Central Java, Indonesia) fruit pericarp was collected, dried and powdered at room temperature naturally. The determination of the powdered material was done at laboratory of Pharmacognocy, Faculty of Pharmacy, Universitas Gadjah Mada. As many as $500 \mathrm{~g}$ of powdered material was extracted with $5 \mathrm{~L}$ of $70 \%$ ethanol for five days at room temperature, blended continuously. The extracts were filtered by sentrifugation and concentrated to remove the solvent using vacuum rotary evaporator, and more than 240.0 $\mathrm{g}$ of crude ethanolic extract was yielded.

\section{Cell Line and Culture}

WiDr colon cancer cells collected by Cancer Chemoprevention Research Center, Faculty of Pharmacy Universitas Gadjah Mada obtained from Prof. Masashi Kawaichi (Nara Institute of Science and Technology, Japan). The cells were maintained in RPMI-1640 (Gibco) supplemented with 10\% FBS (Gibco), penicillin $(10,000 \mathrm{U} / \mathrm{mL})$, streptomycin $(10$ $\mathrm{mg} / \mathrm{mL})($ Gibco) and Fungizone $(0.5 \mathrm{~mL})$ in a humidified atmosphere of $50 \mu \mathrm{g} / \mathrm{mL} \mathrm{CO}_{2}$ at $37^{\circ} \mathrm{C}$.

\section{In Vitro Assay for Cytotoxic Activity (MTT Assay)}

The cytotoxicity of ethanolic extract of pericarps of mangosteen (EPM) on WiDr cells was determined by the MTT assay. Cells $(5 \times$ $10^{3} /$ well) were plated in $100 \mu \mathrm{L}$ of medium/well in 96-well plates. After incubation overnight in a humidified atmosphere $5 \% \mathrm{CO}_{2}$ at $37^{\circ} \mathrm{C}$, EPM was added in various concentrations $(10,15,20,25$ and $30 \mu \mathrm{g} / \mathrm{mL})$. After treatment with EPM, $100 \mu \mathrm{L}$ of 0.5 $\mathrm{mg} / \mathrm{mL}$ MTT ( $\mathrm{pH} 4.7$ ) was added per well and cultivated for another 4 hours, the reaction was stopped by $100 \mu \mathrm{L}$ SDS $10 \%$ in $\mathrm{HCl} 0.01 \mathrm{~N}$ per well. After incubation overnight, the 
absorbance at $595 \mathrm{~nm}$ was measured with ELISA reader (Bio-Rad), using wells without cells as blanks. All experiments were performed in triplicate. The effect of EPM on the proliferation of colon cancer cells was expressed as the \% cytoviability, using the following formula:

$\%$ Cell viability = (absorbance of cell treated - absorbance of control medium) / (absorbance of controll cell - absorbance of control medium)

The concentration of the extract that caused the death of $50 \%$ of the population of cells $\left(\mathrm{IC}_{50}\right)$ was calculated from the linearity of the relationship between the concentration versus percent cell viability.

\section{Observation of Apoptosis Induction by Double Staining Method}

WiDr cells $(50,000$ cells/well $)$ were cultured on coverslips in the 24 well-plate in $1000 \mathrm{~mL}$ of culture media. Then cells were incubated for 24 hours in a $\mathrm{CO}_{2}$ incubator to readapted cells. After incubation, EPM was added in concentration of $\mathrm{IC}_{50}$, the other wells were the control cells and the solvent DMSO (Sigma) control. At the end of incubation, culture medium (RPMI 1640) was washed with PBS (Sigma), and the cover slip was removed from the wells and placed on the object glass and then poured with acridine orange-ethidium bromide (Sigma) as much as $10 \mu \mathrm{L}$. Observation of cell morphology was done by using a fluorescent microscope magnification 10x10. Living cells will fluorescence green with the nucleus intact cells, early apoptosis would be bright green with fragmented or condensed chromatin, late apoptotic will look orange with fragmented or condensed chromatin, and cells that die because of necrosis will be colored orange with a normal structure of the nucleus (Ribble, et al., 2005).

\section{RESULTS AND DISCUSSION}

\section{Interaction of alpha-mangosteen with IKK and VEGF}

The structure optimization of alphamangosteen was done by using Marvin Sketch, while the $3 \mathrm{D}$ form of its protein receptor was created by using YASARA. After that, we docked the compound with binding site of IKK (PDB ID: 2GNG) and VEGF (PDB ID: 2P2I). Based on the molecular docking of alphamangosteen with VEGF, the docking score was lower than its native ligand. This result showed us that interaction of alpha-mangosteen with VEGF was stronger, so alpha-mangosteen could inhibit VEGF in cytotoxic mechanism. In another hand, the docking score of alphamangosteen with IKK was bigger than its native ligand. This result showed that alphamangosteen could not inhibit the stimulation of NFkB by supressing the activity of IKK.

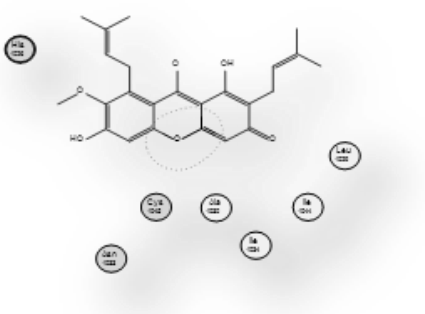

(A)

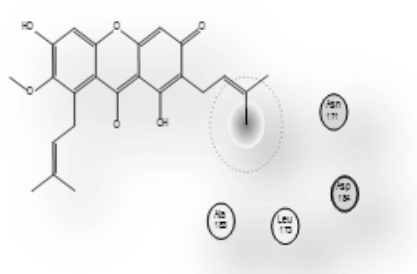

(B)

Figure I. 2D visualization of molecular interaction. Alpha-mangosteen and VEGF (A); alpha-mangosteen and IKK (B); Amino acid of VEGF do more interaction with alpha mangosteen than the IKK. 


\section{Cytotoxicity on WiDr Cells Using MTT Assay}

Cytotoxic activity was tested by in vitro to determine the potential of a compound such as cytotoxic anticancer drugs. Toxicity of a compound was expressed in $\mathrm{IC}_{50}$ value that can inhibit cell proliferation by $50 \%$ of the population. This study used MTT assay to determine the cytotoxic potential of ethanolic extract of pericarps of mangosteen (EPM). The test is based on the measurement of color intensity that occurs as a result of metabolism of a substrate by living cells into colored products. In this test, tetrazolium salt MTT [3-(4,5-dimetiltiazol-2-yl)- 2.5-diphenyl tetrazolium bromide] was used. MTT reduced to formazan by the succinate tetrazolium reductase system, which is included in the mitochondria of living cells. Formazan intensity was measured using ELISA reader at a wavelength of $595 \mathrm{~nm}$. Color intensity is proportional to the number of living cells.

Before being treated with MTT reagent, cell morphology was observed after treatment with EPM for 24 hours. EPM was supplied with various concentrations of 10 , $15,20,25$ and $30 \mu \mathrm{g} / \mathrm{mL}$. Observations showed that the higher concentration of the extract may result in more cell death (Fig. 2). Living cells have leaf morphology and remained attached to the bottom wells, whereas cells undergoing death looked round and not strongly attached to the bottom wells. Black arrows indicate dead cell.

By using ELISA Reader, absorbance values were obtained. Then, the absorbance values were converted into the percentage of living cells. After that, the $\mathrm{IC}_{50}$ value was calculated using the linear regression between extract concentration and percentage of living cells, and obtained $\mathrm{IC}_{50}$ value of $25 \mu \mathrm{g} / \mathrm{mL}$. It showed that EPM with a concentration of 25 $\mu \mathrm{g} / \mathrm{mL}$ could inhibit the proliferation $50 \%$ of WiDr colon cancer cell population. In other words, EPM has cytotoxic effect against WiDr colon cancer cells. In addition, dose- dependent phenomenon which is higher concentration of EPM, lower cell viability dose was also shown by EPM in WiDr colon cancer cells (Fig. 3).

\section{Apoptosis Induction of Ethanolic Extract of Mangosteen Pericarps on WiDr Cells with Double Staining Method}

Apoptosis induction on WiDr cells was performed to determine that cell was dead due to an apoptotic mechanism. Apoptosis characterized by chromatin condensation, nucleus fragmentation and changes in cell morphology (Gewies, 2003; Ricci and Zong, 2006). The assay was done by observing a fluorescent compound that can bind to DNA/RNA and providing a distinctive color in the cell. The compounds used are acridine orange-ethidium bromide. Acridine orange will permeate into the cell and all cells colored green.

Besides, ethidium bromide will only permeate into the cell if the cell loses its membrane integrity and provided red. Color was caused by ethidium bromide on dead cell is more dominant when compared with acridine orange so that the nucleus of dead cells will be orange (Nishioka, et al., 1995). Living cells with intact nucleus of cells will appear green, early apoptosis would be bright green with fragmented or condensed chromatin, late apoptotic will look orange with fragmented or condensed chromatin, and dead cells have necrosis will be colored orange with the normal structure of nucleus (Renvoize, et al., 1998).

EPM showed apoptosis activity (Fig. $4 \mathrm{~b}$ ), where the nucleus appeared orange with fragmented or condensed chromatin. While, it was not visible in the control group with an intact cell nucleus and fluoresces green (Fig. 4a). The result of this staining proves that EPM was able to induce apoptosis on WiDr cells. 


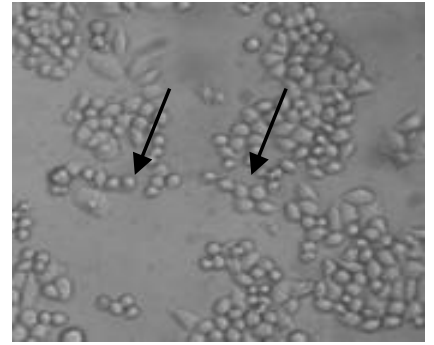

(A)

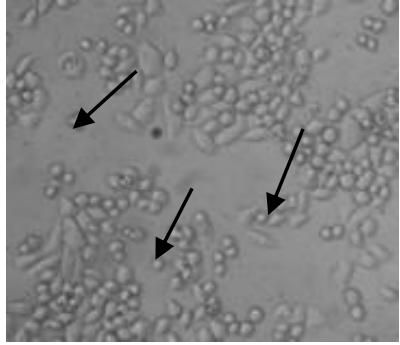

(B)

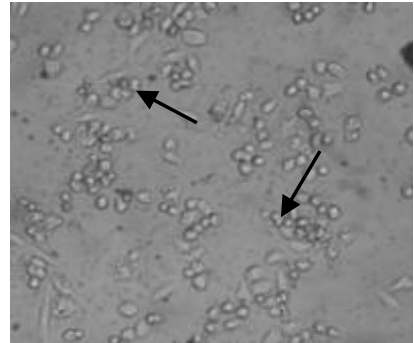

(C)

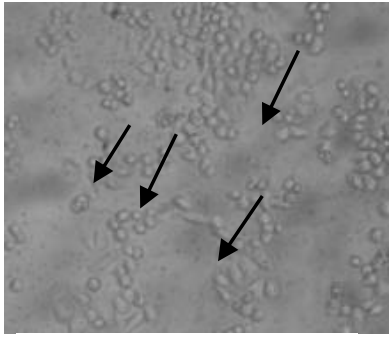

(D)

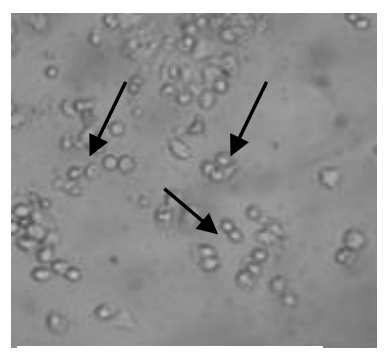

(E)

Figure 2. The cytotoxicity effect of EPM on the morphology of WiDr cells. Treatment of EPM in concentration $10 \mu \mathrm{g} / \mathrm{mL}$ (a), treatment of $15 \mu \mathrm{g} / \mathrm{mL}$ EPM (b), treatment of $20 \mu \mathrm{g} / \mathrm{mL}$ EPM (c), treatment of $25 \mu \mathrm{g} / \mathrm{mL}$ EPM (d), and treatment of $30 \mu \mathrm{g} / \mathrm{mL}$ EPM (e). WiDr cells were incubated for 24 hours, in $5 \%$ $\mathrm{CO} 2$ incubator at $37^{\circ} \mathrm{C}$. Observations made under an inverted microscope with a magnification of 40x. The arrow $(\longrightarrow$ ) indicates cell death at each concentration.

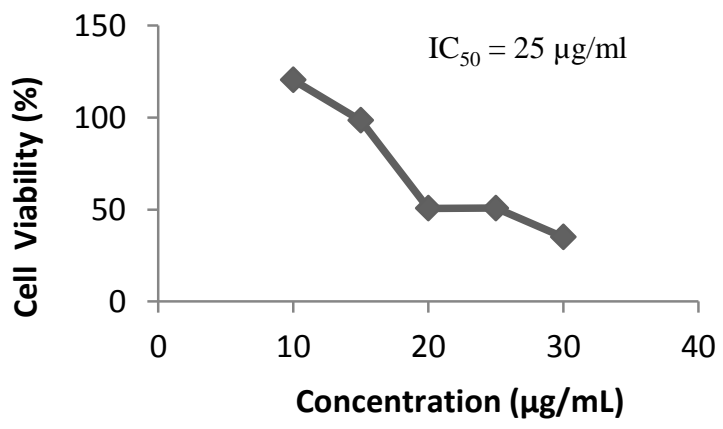

Figure 3.The effect of EPM on the viability of WiDr cells. Graph showed the treatment effect of various concentrations of ethanolic extract of mangosteen pericarps on WiDr colon cancer cell viability.

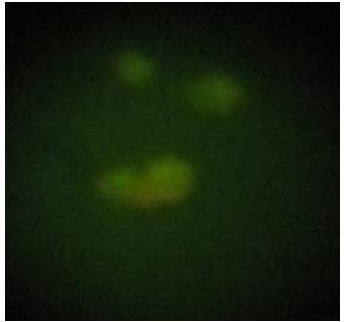

(A)

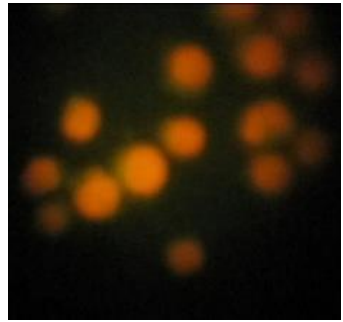

(B)

Figure 4. The apoptosis induction effects of ethanolic extract of pericarp of mangosteen (EPM) on WiDr colon cancer cells. Tests were carried out by incubating $5 \times 10^{4}$ cells per wells for 24 hours. Staining done by using acridine orange-ethidium bromide and was observed using a microscope with a magnification of $400 x$ floresence. (a) Control cell, (b) Cells that undergo apoptosis after treatment were given EPM. Living cells showed green fluorescence whereas dead cells showed orange fluoresence. 
The study focused to determine the potential of ethanolic extract of pericarps of mangosteen (EPM) as chemotherapeutic agents on WiDr cells. The study was conducted by in silico and in vitro interaction studies. First, molecular docking was analyzed the interaction of compound of EPM, alpha-mangosteen, with IKK protein and VEGF. Then the cytotoxic activity of ethanolic extract of mangosteen pericarps (EPM) and induction of apoptosis were tested on colon cancer cells WiDr.

Molecular docking showed that alphamangosteen do not inhibit NFkB modulation through inhibition of IKK activity but possibly other mechanisms. This is a test of the early to predict what path is used EPM in inducing cell death in WiDr cells. The mechanism is likely through the inhibition of the expression or activity of VEGF which further induce apoptosis. However, it needs to be proven by further studies.

Cytotoxic test performed using the MTT assay. The data showed that EPM delivered cytotoxic activity against colon WiDr colon cancer cells with $\mathrm{IC}_{50}$ value of $25 \mu \mathrm{g} / \mathrm{mL}$. With this $\mathrm{IC}_{50}$ value of EPM, the extract can be classified into a potent chemotherapeutic agent (Boik, 2001) which states that crude extract with $\mathrm{IC}_{50}$ less than $100 \mu \mathrm{g} / \mathrm{mL}$ of highly potent as an anticancer agent. Graph of EPM concentration relationship with the percentage of living cells showed dose-dependent phenomenon, which means the higher concentration of the extract is given caused the lower viability of the cells. EPM inhibited the growth of WiDr cells probably caused by the active compounds that have cytotoxic effect. Previous studies mentioned that the pericarps of the mangosteen are rich in xanthon. Compared xanthon other compounds, $\alpha-, \quad \beta-$, and $\gamma$ mangosteen, is the major bioactive compounds found in the pericarps of the mangosteen (Chairungsrilerd, et al., 1996). Cytotoxic activity of alpha-mangosteen known to have effects and apoptosis in liver cancer (Ho, et al., 2002), breast cancer (Moongkarndi, et al., 2004), and colorectal cancer (Nakagawa, et al., 2007). Alpha-mangosteen also inhibited metastasis in cancer cells PC-3 (Hung, et al., 2 7009). Therefore, cells had died because of EPM may be caused by activity of xanthon compounds, especially alpha-mangosteen.

The mechanism of cell death that occurred probably through many pathways including the induction of apoptosis or by inhibition of cell cycle. To determine the possible mechanisms of cell death then induction of apoptosis was observed in $\mathrm{WiDr}$ cells by double staining method. Observations was made qualitatively. The results indicate the presence of cells undergoing flouresence orange, with fragmented cell bodies indicating the occurrence of apoptosis. From these results we can conclude that one mechanism of the cytotoxic ethanolic extract of mangosteen pericarps on WiDr colon cancer cells likely occurred through the induction of apoptosis. Membrane of cells undergoing apoptosis will have bulging out without loss of membrane integrity. Cells then shrank and formed apoptotic bodies. On histological examination, there is no inflammatory cells around the cells undergoing apoptosis (Gavrieli, et al., 1992). This is the advantageous when compared with other way of cell death, necrosis. In the necrosis cells, inflammatory response had been seen around these cells (Thompson, et al., 1992). A potent extract induced apoptosis preferable and more profitable because it did not induce an inflammatory response that did not aggravate the condition of patients with cancer.

There is needed further research to determine the mechanisms of apoptosis induction that occured in WiDr cells which, according to WiDr cell apoptosis can occur through p53 independent pathways, including through the activation of $\mathrm{p} 73$ (Levrero, et al., 2000).

\section{ACKNOWLEDGEMENT}

We acknowledge Student Research Grant (HPM) Program, Universitas Gadjah Mada who has funded this research in 2011.

\section{REFERENCES}

Boik, J, 200I, Natural Compounds in Cancer Therapy, Oregon: Oregon Medical Press.

Chairungsrilerd, N., Furukawa, K., Ohta, T., Nozoe, S. and Ohizumi, Y, 1996, Pharmacological Properties of Alphamangosteen, a Novel Histamine $\mathrm{HI}$ Receptor Antagonist, Eur. J. Pharmacol., 3 I 4(3), 35I-356.

Fujioka, S., Sclabas, G.M., Schmidt, C., Frederick, W.A., Dong, Q.G., et al., 2003, Inhibition of Constitutive NF-kappaB Activity by Ikappa Balpha M Suppresses 
Tumorigenesis, Oncogene, 22(9), 13651370.

Gavrieli, Y., Sherman, Y. and Ben-Sasson, S.A., 1992, Identification of Programmed Cell Ddeath In Situ Via Specific Labeling of Nuclear DNA Fragmentation, J. Cell Biol., I I 9(3), 493-50I.

Gewies, A., 2003, Introduction to Apoptosis, Apo Review, I-26.

Ho, C.K., Huang, Y.L. and Chen, C.C., 2002, Garcinone E, a Xanthone Derivative, has Potent Cytotoxic Effect Against Hepatocellular Carcinoma cell Lines, Planta Med., 68(I I), 975 - 979.

Hung, S.H., Shen, K.H., Wu, C.H., Liu, C.L. and Shih, Y.W., 2009, Alpha-mangosteen Suppresses PC-3 Human Prostate Carcinoma Cell Metastasis by Inhibiting Matrix Metalloproteinase- $2 / 9$ and Urokinase-Plasminogen Expression Through the JNK Signaling Pathway, J Agric. Food Chem., 57(4), I29I-I 298.

Levrero, M., Laurenzi, V.De.,Constanzo, A., Sabatini, S., Gong, J., Wang, J.Y.J. and Melino, G., 2000, The p53/p63/p73 Family of Transcription Factors: Overlapping and Distinct Functions, J. Cell. Sci., I I3(I0), I 66 I-I670.

Matsumoto, K., Akao, Y., Ohguchi, K., Ito, T., Tanaka, T., linuma, M., et al., 2005, Xanthones Induce Cell-cycle Arrest and Apoptosis in Human Colon Cancer DLDI Cells, Bioorg. Med. Chem., I3(2I), 60646069.

Moongkarndi, P., Kosem, N., Kaslungka, S., Luanratana, O., Pongpan, N. and Neungton, N., 2004, Antiproliferation, Antioxidation and Induction of Apoptosis by Garcinia mangostana (mangosteen) on SKBR3 Human Breast Cancer Cell Line, J. Ethnopharmacol., 90(I), I6I-166.

Nabandith, V., Suzui, M., Morioka, T., Kaneshiro, T., Kinjo, T., Matsumoto, K., et al., 2004, Inhibitory Effects of Crude alpha-mangosteen, a Xanthone Derivative, on Two Different Categories of Colon Preneoplastic Lesions Induced by I, 2dimethylhydrazine in The Rat, Asian Pac. J. Cancer Prev., 5(4), 433-438.

Nakagawa, Y., linuma, M., Naoe, T., Nozawa, Y. and Akao, Y., 2007, Characterized Mechanism of Alpha-mangosteen-Induced Cell Death: Caspase-Independent Apoptosis with Release of Endonuclease$\mathrm{G}$ from Mitochondria and Increased miR143 Expression in Human Colon Cancer DLD-I Cells, Bioorg. Med. Chem., I5(I6), 5620-5628.

Renvoizé, C., Biola, A.M., Pallardy, M. and Bréard, J., 1998, Apoptosis: Identification of Dying Cells, Cell Biol. Toxicol., I4, III120.

Ribble, D., Goldstein, N.B., Norris, D.A. and Shellman, Y.G., 2005, A Simple Technique for Quantifying Apoptosis in 96-well Plates, BMC Biotechnol, 5, 12.

Ricci, M.S. and Zong, W., 2006, Chemotherapeutic Approaches for Targetting Cell Death Pathways, Oncologist, I I (4), 342-357.

Thompson, H.J., Strange, R. and Schedin, P.J., 1992, Apoptosis in the Genesis and Prevention of Cancer, Cancer Epidemiol. Biomarkers Prev., I (7), 597-602.

Turini, M.E. and Dubois, R.N., 2002, Cyclooxygenase-2: A Therapeutic Target, Ann. Rev. Med., 53, 35-57.

Weecharangsan, W., Opanasopit, P., Sukma.M., Ngawhirunpat, T., Sotanaphun, U., et al., 2006, Antioxidative and Neuroprotective Activities of Extracts from the Fruit Hull of Mangosteen (Garcinia mangostana Linn.), Med. Princ. Pract., I 5(4), 28I-287.

Winawer, S.J., 2007, The multidisciplinary management of gastrointestinal cancer. Colorectal cancer screening, Best Pract. Res. Clin. Gastroenterol., 2 I (6), I03 I-I048. 